\title{
Література:
}

1. Григоренко В. Г. Феномен психомоторних здібностей та психосоматичного здоров'я в процесі соціально-цінністного самовизначання учнів загальноосвітньої школи. Гуманізація навчально-виховного процесу: збірник наукових пращь за заг. ред. В. І.Сипченко. Слов'янськ, 2012. Вип. LIX, ч. 2. С. 192-206.

2. Ковальчук Н.М., Санюк В. І. Рухливі ігри на заняттях із гімнастики: методична розробка. Луцьк: Вежа-Друк, 2018. 92 с.

3. План заходів з реалізації Національної стратегії безпечного і здорового освітнього середовища в Новій українській школі на 2021 рік. https://zakon.rada.gov.ua/laws/show/1668-2020

4. Стасенко О.А. Організація фізкультурно-оздоровчої роботи у загальноосвітніх навчальних закладах: шляхи та перспективи. Молодий вчений, 2016. № 9.1 (36.1). С. 151-157.

5. Твердохліб Ж.О., Погребенник Л.І. Рухливі ігри для сучасної школи: Методичні матеріали. Житомир: Вид-во ЖДУ ім. І. Франка, $2011.62 \mathrm{c}$.

\section{DOI https://doi.org/10.30525/978-9934-26-041-4-41}

\section{ОСОБЛИВОСТІ ЕКОЛОГІЧНОГО ВИХОВАННЯ ТА ЕМОЦІЙНОГО СТАВЛЕННЯ ДО ПРИРОДИ ДІТЕЙ СТАРШОГО ДОШКІЛЬНОГО ВІКУ}

\author{
Добровольська Л. П. \\ кандидат педагогічних наук, \\ дочент кафедри дошкільної освіти і соиіальної роботи \\ Мелітопольський державний педагогічний університет \\ імені Богдана Хмельнищького \\ м. Мелітополь, Запорізька область, Україна
}

\begin{abstract}
Сьогодні, у добу соціально-економічних перетворень в нашій державі й водночас на фоні глобального погіршення стану довкілля проблема екологічної освіти дитини, у майбутньому - дорослої людини, є конче важливою та потребує обміркованих рішень від держави, закладів освіти, сім’ї та громадських об'єднань. Низький рівень екологічної культури людей, прагнення їх до збагачення, ігнорування морально-етичними та правовими нормами експлуатації природних ресурсів, їх недоцільне
\end{abstract}


використання спричинили кординальне порушення балансу $\mathrm{y}$ природному та соціальному довкіллі.

Доречно нагадати, що природне довкілля - це явище природи, жива і нежива природа, за якими спостерігає дитина. Предметне довкілля це предметне середовище, в якому дитина живе, це предмети побуту (посуд, меблі, одяг тощо), мистецтво, транспорт тощо. Соціальне довкілля - це система взаємовідносин, що склалась у суспільстві, в конкретному соціумі; це люди, суспільство, певна спільнота [1, с. 12].

Доцільно відзначити, що складовою сучасної освіти є екологічний компонент, який включає: формування екологічної культури 3 наймолодшого віку шляхом опанування дітьми екологічними компетентностями й виховання на їхній основі гуманного ставлення до природного довкілля як до загальнолюдської цінності, набуття 3 раннього віку досвіду гармонійної взаємодії з природою [2, с. 4].

Цікаві погляди на природу як засіб виховання підкреслюються у спадщині вітчизняних педагогів К. Ушинського, С. Русової, $€$. Водовозової, Є. Тихєєвої та В. Сухомлинського. Методики ознайомлення дошкільників із довкіллям, зокрема й 3 природою, широко розглядалися в працях Г. Васильевої, Н. Виноградової, К. Золотової, Т. Куликової, М. Лучич, Г. Мазуриної, М. Марковської, П. Саморукової, І. Хайдурової, Н. Яришевої та інших.

Варто підкреслити, що зміст сучасної екологічної освіти дітей дошкільного віку формується відповідно до державних документів, які регламентують діяльність українського дошкілля (Концепції дошкільного виховання в Україні, Законі України «Про дошкільну освіту», Програмах розвитку дитини дошкільного віку, Національній програмі виховання дітей та учнівської молоді в Україні, Національній доктрині розвитку освіти та Базовому копоненті дошкільної освіти). У них чітко означені базові засадти та виокремлено принципи екологічної освіти українських дошкільників. Це принципи гуманізації, природовідповідності, етнізації та неподільної єдності теорії з практикою пізнання довкілля i природокористування на науковій основі й автентичних народних традиціях. Такі методологічні позиції співзвучні зі стратегію «Білої книги національної освіти України» [2, с. 5].

12 січня 2021 року було прийнято оновлений Базовий компонент дошкільної освіти, в якому означено освітні лінії. Однією 3 найважливіших є освітня лінія «Дитина в природному довкіллі», яка складається 3 природничо-екологічної компетентності та навичок, орієнтованих на сталий розвиток. Якщо у Базовому компоненті 2012 році компетентність полягала у обізнаності дитини 3 природним середовищем Землі i Всесвіту, як цілісною системою, в якій взаємодіють всі сили природи, Сонце, Місяць і людина та усвідомлені 
їх значення для людей і для себе, сприймані природи як цінності, то в новому Базовому компоненті компетентність полягає у здатності дитини правильно реагувати в різних життєвих ситуаціях на основі емоційно-цілісного ставлення до природи та знанні її законів.

Н. Лисенко визначає зміст дефініції «екологічна освіта дітей дошкільного віку» як свідомо та доцільно спланована систематична i поетапна діяльність педагога 3 дітьки задля реалізації завдань екологічної освіти за умови їх активної участі в різних видах діяльності. Саме вихователь 3 дошкільного віку вводить дітей у правовий контекст пізнання, використання і охрани природи відповідно до міжнародних угод і програм [2, с. 9-10].

Екологічна культура сучасного дошкільника - завтрашнього дорослого споживача природних багатств, повинна спрямовуватись на протидію з усталеними традиціями становлення до природи, боротьбу за альтернативні алгоритми вирішення екологічних проблем [2, с. 4].

Екологічний світогляд дітей дошкільного віку повинен формуватися шляхом екологізації в різних видах діяльності освітнього процесу закладу дошкільної освіти.

Д. Ушинський вважав логіку природи самою доступною для дитини. Організовуючи спостереження, практичну діяльність вихованців під час екскурсій, педагог допомагає їм встановлювати причинні і тимчасові зв'язки, залежності між фактами і явищами оточуючої природи, порівнювати, робити узагальнення та висновки [4, с. 370].

В. Сухомлинський у книзі «Серце віддаю дітям» описує, з яким захопленням старші дошкільнята малюють те, що спостерігали на екскурсіях, наводить тексти вигаданих ними оповідань, казок про природу, працю людей. Безсумнівно, що такі заняття розвивають творчість, сприяють тому, що розуміння краси природи стає більш усвідомленим і глибоким [4, с. 373].

На думку відомого англійського культуролога і екофілософа Джона Раскіна, любов до природи - безумовно, саме здорове почуття, несумісне зі злими пристрастями: «Відсутність любові до природи не $\epsilon$ безсумнівним недоліком, але наявність цього почуття - обов'язкова ознака доброго серця й справедливого морального відчуття, ступінь глибини цього почуття, ймовірно, визначає і ступінь шляхетності й краси характеру».

Дошкільник надзвичайно чутливий, емочійно сприймає побачене та почуте, активно співчуває, переживає. Особливо його захоплює можливість долучатися до розв'язання проблем довкілля. I за умови системного педагогічного впливу в дітей формується почуття відповідальності, ототожнення себе з усією людською спільнотою. Дошкільнята мають навчитися дивитися на світ природи добрими 
очима. Коли дитина із самого дитинства усвідомить важливість природи в житті кожної людини, зрозуміє це розумом і серцем - вона стане справжньою Людиною.

Слід зауважити, що виховання емоційно-ціннісного ставлення до природи у дітей старшого дошкільного віку неможливе без інтеграції роботи педагогічного колективу та сім'ї, оскільки сім'я й дитячий садок мають свою специфіку, особливості впливу на дитину, свої виховні засоби. Зрозуміло, екологічний розвиток дітей в закладі дошкільної освіти буде особливо ефективним, якщо він взаємопов'язаний з екологічним вихованням у сім'ї. Тому педагоги повинні спонукати батьків до створення сприятливих умов щодо еколого-розвивального середовища.

Сприйняття краси природи, звичайно, підсилює емоційне ставлення до неї дитини і тому є конче важливим виховним моментом.3 погляду екологічного виховання, необхідно дати зрозуміти дитині, що зовнішній вигляд будь-якого організму - це результат його пристосування до життя у певних умовах, навчити розуміти красу як прояв доцільності, усвідомлювати необхідність існування будь-якого організму незалежно від наших симпатій і антипатій. Не обов'язково любити усіх тварин, усі рослини, але поважати цсі форми прояву життя необхідно. Оцінні судження стосовно об'єктів природи повинні бути виключені з екологічної освіти дошкільників. 3 позиції біоцентризму (екоцентризму) живі організми не можуть бути гарними або поганими, корисними або шкідливими. Вони мають рівне з людиною право на існування, кожний з них грає свою, виняткову роль у природі. Догляд за живими організмами, турбота про них мають величезний емоційний вплив на дитину. Але при цьому вона повинна розуміти: у дикій природі допомога людини, якщо вона дійсно необхідна, повинна бути добре продуманою [4, с. 29-30].

Гармонія взаємодії людини 3 природним довкіллям як один із законів загальноосвітньої необхідності доводить доцільність якомога швидшого введення дітей у сутність системи «природа - людина суспільство - приирода» [3, с. 3].

Таким чином, природа $є$ основним фактором існування людини, вона й людство невіддільні одне від одного. Безсумнівно, що особливості екологічного виховання та емоційного ставлення до природи слід починати 3 дошкілля. Саме в цей період дитина вперше знайомиться 3 природним довкіллям, проявляє пізнавальну активність, спостережливість, допитливість та продовжує формувати уявлення про природу та особливості природних явищ. 


\title{
Література:
}

1. Богуш А. М., Гавриш Н. Методика ознайомлення дітей 3 довкіллям у дошкільному навчальному закладі: підруч. для ВНЗ: Київ: Слово 2008. 408 с.

2. Лисенко Н. В. Еко-око: дошкільник пізнає світ природи : навчально-методичний посібник. Київ : Слово, 2015. 352 с.

3. Лисенко Н. В. Теорія і практика екологічної освіти: дошкільникпедагог. Навчально-методичний посібник для ВНЗ. Київ.6 Видавничий дім «Слово».2009. $400 \mathrm{c}$.

4. Горопаха Н. М.Методика ознайомлення дітей 3 природою. Хрестоматія. Київ, 2012. 432 с.

\section{DOI https://doi.org/10.30525/978-9934-26-041-4-42}

\section{ЗАБЕЗПЕЧЕННЯ ГЕНДЕРНОЇ РІВНОСТІ У СИСТЕМІ ВИЩОЇ ОСВІТИ}

\author{
Дорощук М. Г. \\ аспірант кафедри педагогіки, професійної освіти \\ та управління освітніми закладами \\ Науковий керівник: Давидюк М. О. \\ кандидат педагогічних наук, \\ доцент кафедри педагогіки, професійної освіти та управління \\ освітніми закладами \\ Вінницький державний педагогічний університет \\ імені Михайла Кочюбинського \\ м. Вінниця, Украӥна
}

Від початку розвитку людської цивілізації у різних типах спільнот етнічних, територіальних, професійних - існувала нерівність між чоловіками і жінками. Об'єктивна нерівність складалася історично та інтерпретувалась до недавнього часу як на рівні побутовому, так і в наукових наративах як належний порядок або як частина порядку Божественного (що підкріплювалося цитатами зі Святого Письма та інших культових книг). Упродовж тисячоліть ні чоловіки, ні жінки фактично не замислювалися над тим, що таке права жінок і дискримінація за статтю. 